\title{
Tecnical Note: Analysis of non-regulated vehicular emissions by extractive FTIR spectrometry: tests on a hybrid car in Mexico City
}

\author{
F. Reyes ${ }^{1}$, M. Grutter ${ }^{1}$, A. Jazcilevich ${ }^{1}$, and R. González-Oropeza ${ }^{2}$ \\ ${ }^{1}$ Centro de Ciencias de la Atmósfera, Universidad Nacional Autónoma de México, 04510 México D.F., Mexico \\ ${ }^{2}$ Facultad de Ingeniería, Universidad Nacional Autónoma de México, 04510 México D.F., Mexico
}

Received: 2 May 2006 - Published in Atmos. Chem. Phys. Discuss.: 3 July 2006

Revised: 4 October 2006 - Accepted: 16 November 2006 - Published: 27 November 2006

\begin{abstract}
A methodology to acquire valuable information on the chemical composition and evolution of vehicular emissions is presented. The analysis of the gases is performed by passing a constant flow of a sample gas from the tail-pipe into a $10 \mathrm{~L}$ multi-pass cell. The absorption spectra within the cell are obtained using an FTIR spectrometer at $0.5 \mathrm{~cm}^{-1}$ resolution along a $13.1 \mathrm{~m}$ optical path. Additionally, the total flow from the exhaust is continuously measured from a differential pressure sensor on a Pitot tube installed at the exit of the exhaust. This configuration aims to obtain a good speciation capability by coadding spectra during $30 \mathrm{~s}$ and reporting the emission (in $\mathrm{g} / \mathrm{km}$ ) of both criteria and non-regulated pollutants, such as $\mathrm{CO}_{2}, \mathrm{CO}, \mathrm{NO}, \mathrm{SO}_{2}$, $\mathrm{NH}_{3}, \mathrm{HCHO}$ and some $\mathrm{NMHC}$, during predetermined driving cycles. The advantages and disadvantages of increasing the measurement frequency, as well as the effect of other parameters such as spectral resolution, cell volume and flow rate, are discussed. To test and evaluate the proposed technique, experiments were performed on a dynamometer running FTP-75 and typical driving cycles for the Mexico City Metropolitan Area (MCMA) on a Toyota Prius hybrid vehicle. This car is an example of recent marketed automotive technology dedicated to reduced emissions, increasing the need for sensitive detection techniques. This study shows the potential of the proposed technique to measure and report in real time the emissions of a large variety of pollutants, even from a super ultra-low emission vehicle (SULEV). The emissions of $\mathrm{HC}$ 's, $\mathrm{NO}_{\mathrm{x}}, \mathrm{CO}$ and $\mathrm{CO}_{2}$ obtained here were compared to experiments performed in other locations with the same model vehicle. The proposed technique provides a tool for future studies comparing in detail the emissions of vehicles using alternative fuels and emission control systems.
\end{abstract}

Correspondence to: M. Grutter
(grutter@ servidor.unam.mx)

\section{Introduction}

Automotive emissions are a major component in the formation of photochemical smog in many modern cities. For example in the Mexico City Metropolitan Area (MCMA), over $99 \%$ of carbon monoxide (CO), $83 \%$ of nitrogen oxides $\left(\mathrm{NO}_{\mathrm{x}}\right), 20 \%$ of ammonia $\left(\mathrm{NH}_{3}\right)$ and $38 \%$ of volatile organic hydrocarbons (VOC) that are emitted to the atmosphere originate from mobile sources according to the local emissions inventory (GDF, 2002). Substantial progress in automotive technology such as catalytic converters, fuel injection systems and improved gasoline formulations has allowed a considerable reduction in emissions per car, but has considerably been offset by the rapid increase in both car population and use.

One relatively recent innovation in car technology to enter the market is the gas-electric hybrid car. It has become a realistic way of considerably reducing gasoline consumption and lowering pollutant emissions. Hybrid cars do not sacrifice the autonomy of conventional vehicles since they are powered by an internal combustion engine (IC) using regular gasoline and an alternating electrical synchronous motor that provides torque either in parallel or in series. A battery pack is recharged by the IC when needed but also during deceleration or braking when the electric motor acts as a generator. Comprehensive studies of Toyota and Honda hybrid vehicles (NREL, 2001; EPA, 1998; EPA, 2005) have shown that these technologies can achieve notably high efficiencies and ultralow emissions.

Advances like the gas-electric hybrid system to power automobiles and the growing concern for the protection of the environment have been forcing vehicle exhaust emissions to be reduced to an extremely low level while increasing achievable fuel economy. Such a decrease in pollutant concentrations is a challenge for emissions measuring systems and requires improvements in the analytical techniques as a whole, including the gas analyzers and the sample handling systems

Published by Copernicus GmbH on behalf of the European Geosciences Union. 


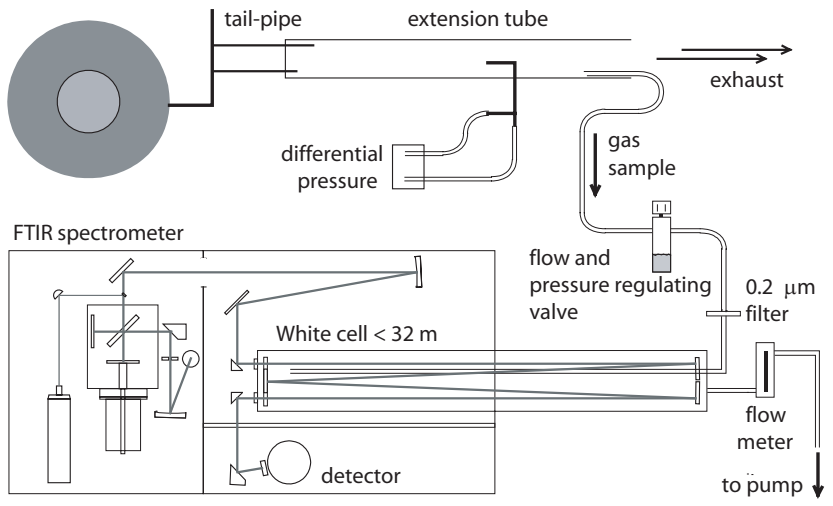

Fig. 1. Schematic diagram of the exhaust analysis system composed of a flow measurement tube, a sample line, water extraction valve, filters, gas cell and FTIR spectrometer.

(Adachi, 2000). Non-criteria gaseous emissions such as ammonia $\left(\mathrm{NH}_{3}\right)$, nitrous oxide $\left(\mathrm{N}_{2} \mathrm{O}\right)$, aldehydes, aromatics, alcohols and other toxic and reactive compounds are receiving increased attention for their impact on human health and their potential in the formation of photochemical smog including secondary aerosols. New experimental methods to continuously monitor these pollutants are being developed.

$\mathrm{NH}_{3}$ is an important non-regulated gas emitted by cars. It has been shown experimentally that $\mathrm{NH}_{3}$ emissions from vehicles may be more significant than previously thought (Durbin et al., 2001; Fraser et al., 1998; Shores et al., 2000; Kean et al., 2000; Baum et al., 2000; Gertler et al., 2001). This could contribute to increased levels of aerosols having health implications and playing an important role in the atmospheric chemistry of urban air (Finlayson-Pitts et al., 2000). It has been shown that the large concentrations of gaseous $\mathrm{NH}_{3}$ detected in Mexico City, peaking $>30 \mathrm{ppb}$ in some places, are converted to accumulation mode aerosols (Moya et al., 2004). The emissions of $\mathrm{N}_{2} \mathrm{O}$ have also been investigated and need to be properly regulated since it is an important greenhouse gas (Berges et al., 1993; Ballantyne et al., 1994; Michaels et al., 1998; Baronick et al., 2000) having a global warming potential 296 times greater of that of carbon dioxide (IPCC, 2001). The global atmospheric concentration of $\mathrm{N}_{2} \mathrm{O}$ has steadily increased $1.5 \mathrm{ppb} /$ year in the past two decades, and is now $16 \%$ (46 ppb) larger than before the start of the Industrial Era (1750).

Since $\mathrm{N}_{2} \mathrm{O}$ and $\mathrm{NH}_{3}$ are primarily formed in reactions that occur on the reduction catalyst surface, their emissions need to be investigated in specific operating conditions and for specific fuel types. Only the more recent emissions inventory of the Mexico City Metropolitan Area (GDF, 2002) includes ammonia, although the estimates are calculated based on studies made on other locations rather that from measurements performed locally. These estimates need to be reconsidered based on real observations in order to determine more precisely what fraction of the total ammonia and $\mathrm{N}_{2} \mathrm{O}$ emis- sions in the city originate from mobile sources.

FTIR (Fourier Transform Infrared) spectroscopy is now considered a valuable and useful tool for vehicle emission analysis due to its multicomponent analysis capability, sensitivity and time resolution (Adachi, 2000; Durbin, 2002). It is especially well suited for monitoring non-regulated pollutants when testing alternative fuels and newer emissioncontrol technologies. The FTIR technique is a well established methodology which has been validated by several regulatory and standardization agencies for extractive gassampling analysis (EPA, 1998a; NIOSH, 2000; VDI, 2000; ASTM, 2002; CARB, 2004). It is known as a reliable, selfvalidating (in terms of post-analysis verifications) and powerful method, capable of monitoring several gaseous pollutants simultaneously.

As opposed to the widely used constant volume sampler (CVS), the FTIR technique does not require dilution, which in the case of the ultra low emission vehivles (ULEV) or the SULEV, becomes a problem since the concentrations of pollutants are more difficult to detect and monitor with sufficiently high-response times. The CVS systems may run into the problem that the pollutant concentrations from the low emission vehicles may be similar to those in the ambient air used for the dilution. FTIR can measure the raw exhaust directly. Many highly reactive species in the exhaust can be measured by FTIR even below the part-per-million levels, replacing several discrete analyzers which may require complicated calibration procedures. The sampling techniques, however, remain advantageous when detailed analysis is desired, such as complete hydrocarbon speciation achievable with gas chromatographic methods.

The objective of this study was to develop a methodology to measure in real-time detailed emissions of vehicular exhausts using FTIR spectroscopy. Particular emphasis was placed on evaluating emissions of regulated and nonregulated gases such as $\mathrm{NH}_{3}, \mathrm{~N}_{2} \mathrm{O}, \mathrm{NO}, \mathrm{CH}_{4}$, non-methane hydrocarbons $\left(\mathrm{C}_{2} \mathrm{H}_{2}, \mathrm{C}_{2} \mathrm{H}_{4}, \mathrm{C}_{2} \mathrm{H}_{6}\right)$, formaldehyde $\left(\mathrm{H}_{2} \mathrm{CO}\right)$ and methanol $\left(\mathrm{CH}_{3} \mathrm{OH}\right)$ as part of an ongoing project to improve the emission inventories used in air quality models.

\section{Experimental section}

Emission experiments were preformed on a Toyota 2002 Prius Hybrid vehicle on a dynamometer facility located at the Department of Engineering (UNAM), running typical MCMA driving cycles. Emission factors were obtained from the FTIR spectroscopic measurements in conjunction with exhaust flows determined with a Pitot tube installed on the tail-pipe.

The general set-up used for vehicle exhaust analysis is depicted in Fig. 1. It consists of a test vehicle on a chassis dynamometer, a mass flow measurement system on the tailpipe, a sample extraction line, a gas cell and an FTIR spectrometer. The gas sample is drawn from a stainless steel 
extension tube by a probe connected to an unheated Teflon hose (length: $2.3 \mathrm{~m}, \mathrm{ID}: 3 / 16 \mathrm{in}$ ), which is pumped at a constant flow of 26 liters $\mathrm{min}^{-1}$. Before entering the 10 liter gas cell, which was heated to $185^{\circ} \mathrm{C}$ and held at a constant pressure of $400 \mathrm{mbar}$, the sample gas passes through a flow and pressure-regulating valve and a $0.2 \mu \mathrm{m}$ porous particle filter. The flow time between the tail-pipe and analytical region is $3 \mathrm{~s}$.

\subsection{On-line measurements of non-regulated gases}

The FTIR spectrometer used for the analysis is the same instrument deployed previously for the measurement of ambient air in the MCMA both in the extractive configuration (Grutter, 2003a) and along a $426 \mathrm{~m}$ open-path (Grutter, 2003b). The interferometer is a Nicolet ${ }^{\circledR}$ Nexus with a maximum unapodized resolution of $0.125 \mathrm{~cm}^{-1}$, which is equipped with a $\mathrm{ZnSe}$ beamsplitter and a $\mathrm{N}_{2}(\mathrm{l})$ cooled MCT detector. The operating spectral range is 700 to $4000 \mathrm{~cm}^{-1}$. The pollutant gas concentrations are retreived from the measured spectra with a non-linear least-squares algorithm. Reference spectra are synthetically generated from the HITRAN spectral database when available (Rothman, 2005), or from infrared libraries. In order to avoid interferences from ambient pollutant levels, a spectrum before and after the experiment from ventilated laboratory air was taken and used as background.

A detailed discussion of the optimal parameters used for the analysis of exhaust gases from vehicles by FTIR spectroscopy has been reviewed elsewhere (Adachi, 2000; Larry, 1986). Basically, the main factors to be considered are spectral resolution, scanning velocity, optical path length, cell volume and sampling flow-rate. The first three factors define the sensitivity of the measurement while the spectrometer's response time will be determined by the latter two. At lower spectral resolutions $\left(\geq 1 \mathrm{~cm}^{-1}\right)$, higher signal-to-noise leads to lower detection limits and higher response times of the spectrometer, whereas selectivity will greatly be affected by interferences of other absorbing species. For this application, the spectral resolution, mirror velocity and integrating time were set at $0.5 \mathrm{~cm}^{-1}, 1.9 \mathrm{~m} / \mathrm{s}$ and $25 \mathrm{~s}$, respectively. The optical-path within the closed "White" cell was set at $13.1 \mathrm{~m}$, corresponding to 16 passes, to avoid saturated absorptions for some gases. These parameters were chosen to obtain good sensitivity and speciation capability rather than a fast response, which in this case is limited by the sample flow time through the cell. With the given cell volume and sample flow rate, the sample renewal time was approximately $\sim 20 \mathrm{~s}$. Experiments with higher system's response times $(5 \mathrm{~s})$ can be achieved by replacing the gas cell with one of smaller volume $(0.75 \mathrm{~L})$ and operating the spectrometer at lower spectral resolutions $\left(1.0 \mathrm{~cm}^{-1}\right)$, but the results of these tests are not included in the present contribution. In Fig. 2a, one can observe the dependence of the relative spectral noise, calculated as the root-mean-square (RMS) in the $2400-2500 \mathrm{~cm}^{-1}$
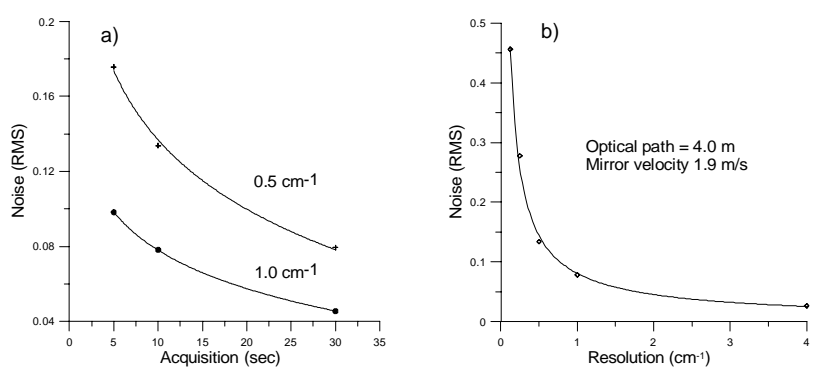

Fig. 2. (a) Spectral noise expressed as the root-mean-square (RMS) in the region $2400-2500 \mathrm{~cm}^{-1}$ as a function of acquisition time for 0.5 and $1.0 \mathrm{~cm}^{-1}$ resolutions. (b) Spectral noise versus spectral resolution keeping the acquisition time constant.

spectral window, with acquisition time for two different spectral resolutions. The spectral noise can be related to the sensitivity since the concentrations of the gases are retrieved from the measured spectra by a non-linear least-squares algorithm. Similarly, the noise is plotted against the spectral resolution in Fig. 2b, where a fast decrease in sensitivity is observed for the higher spectral resolutions, a $0.5 \mathrm{~cm}^{-1}$ spectral resolution was chosen for this study.

\subsection{Flow measurements}

The mass flow rate was measured directly in the exhaust stream, although it is also possible to determine it from the intake flow (prior to the compressor) or after the compressor prior to the engine. The exhaust stream is the most logical choice since this would be a direct measurement of the stream associated with the emissions that are being measured (Mridul, 2001). The vehicle tail-pipe was connected to a stainless steel extension tube (length: $1.4 \mathrm{~m}$; ID: $2.5 \mathrm{in}$.), which was equipped with a Pitot tube centered within the extension tube allowing a direct measurement of the dynamic and static pressures by means of a low-differential pressure transmitter (Cole-Parmer A068071-18, range 0-0.62 mbar) and a K-type thermo-couple. The signals where averaged and registered with a National Instruments ${ }^{\circledR}$ card (DAQ-6035) every $1 \mathrm{~s}$ running under the LabView ${ }^{\circledR}$ environment. From this information, the gas velocity within the extension tube and thus the flow rate could be calculated. A comparison and calibration of the flow rate from the Pitot tube in the 1101340 liter $\mathrm{min}^{-1}$ range could be performed against a hot-wire system (Dantec. Stream Line 90N10). A plot of this data, presented in Fig. 3, shows a deviation from linearity in the lower end of this range, associated with the limited sensitivity of the Pitot tube system. Mass-flow rates for the tickover mode, however, where measured independently, averaged and used where appropriate. 


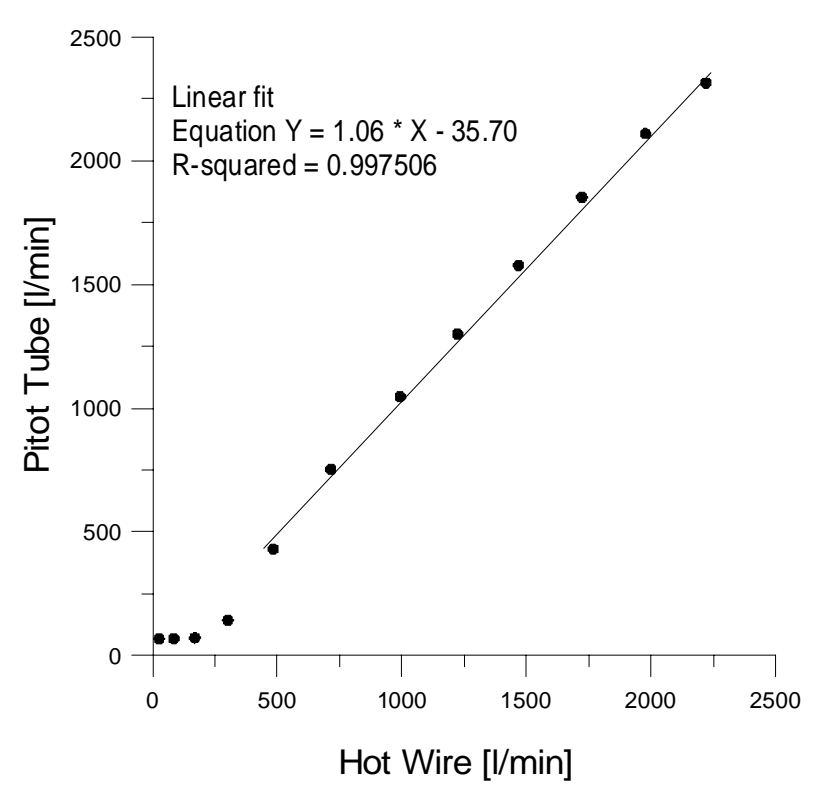

Fig. 3. Calibration curve of the tail-pipe flow rate measured continuously with the Pitot tube versus a hot-wire system.

\subsection{Test vehicle}

The test vehicle was a Toyota Prius Hybrid System (THS) model 2002, that was lent to the University by the Mexican Ministry of the Environment (INE-SEMARNAT) for a 2 -week period. This vehicle is powered by an internal combustion engine (16-valve, 1.5-liter displacement, in line 4cylinder engine) using the local regular unleaded gasoline PEMEX Magna (DGN-SECOFI, 1994) and an alternating electrical synchronous motor. The electric drive is composed of a permanent magnet $\mathrm{AC}$ synchronous motor, a generator, an inverter and a nickel-metal hydride battery pack, which is recharged during deceleration or breaking allowing it to operate as a regular light-duty vehicle. The 2002 hybrid motor is capable of producing 58 horsepower at $4000 \mathrm{rpm}$. For more details on the THS the reader is advised to access (http://www.toyota.com/prius/).

\subsection{Dynamometer and driving cycles}

A chassis dynamometer built by the Department of Engineering of UNAM (Santiago et al., 2000) was used for the emission tests. The rolls supporting the front wheels of the vehicle are equipped with magnetic brakes that apply a constant force during the driving cycle in order to simulate the mass of the vehicle. This does not reproduce the full effect of vehicle inertia. The magnitude of the applied resistance was based from values determined in previous studies.

Five driving cycles developed for different regions of Mexico City (González et al., 2003), labeled according to section of the city ( $\mathrm{SO}=$ south-west, $\mathrm{CE}=$ center, $\mathrm{NE}=$ north- east, $\mathrm{NO}=$ north-west, $\mathrm{SE}=$ south-east), comprise the MCMAsequence used in these experiments. Each cycle is between 323 and $1002 \mathrm{~s}$ long and the entire sequence is more than $1 \mathrm{~h}$ long. Cycles of the Federal Test Procedure (FTP-75) were also run at the dynamometer for comparison purposes. As can be expected from the traffic conditions in Mexico City and the reduced number of highways, the MCMA sequence has a much lower average velocity $(17 \mathrm{~km} / \mathrm{h})$ than the FTP75 cycle $(45 \mathrm{~km} / \mathrm{h})$, commonly used in the United States for evaluating vehicular emissions.

\section{Results and discussion}

The test vehicle and dynamometer were instrumented so that the following parameters were registered during the driving sequence: velocity, rpm, torque, power, temperature of the oil, temperatures before and after the catalytic filters, voltage and current from the battery pack, flow and temperature at the tail-pipe. Moreover, fuel consumption and distance were registered before and after every driving cycle. In Fig. 4, some of these parameters are plotted during a coldstart sequence. It can be seen by following the revolutionsper-minute (rpm) curve that the internal-combustion engine of the hybrid vehicle is permanently on during the first 6 to 9 min when started in cold conditions, although this may vary depending on the state-of-charge of the battery pack. The rpm's, which were measured directly at the spark-plugs by a reflective sensor, HOA1405, correlate very well with the mass-flow measured at the tail-pipe by the Pitot tube. The information acquired during the cycles, together with the concentration of various gases measured at the tail-pipe with the FTIR spectrometer, allowed for the determination of emission factors either in mass units per volume of fuel consumed or per distance traveled. Even though the concentration of the gases increases at the tail-pipe due to accumulation when the IC engine stops, as can be seen at $\sim 500 \mathrm{~s}$ in Fig. 4 , the calculated emissions during these events cancels out since the mass flow at the tail-pipe is zero. These events become more frequent as the hybrid vehicle reaches a quasi steady-state. The evolution of certain gases, as will be shown later, can also be followed and analyzed along specific driving conditions. Data of six MCMA sequences on the Prius 2002 were used to calculate the emission levels presented here. The average emissions from three cold-start MCMA sequences and three hot-start sequences, together with four FTP-75 cycles (bag \#3) run for comparison purposes, are presented in Table 1. It is evident when comparing the results from the local MCMA to the more widely used driving FTP sequence, that the emissions of some pollutants depend strongly on local driving patterns and habits. This could have important impacts on estimated emission factors from mobile sources at various locations.

Table 2 presents a summary of the results from other studies as well as this work. Although an evaluation of 


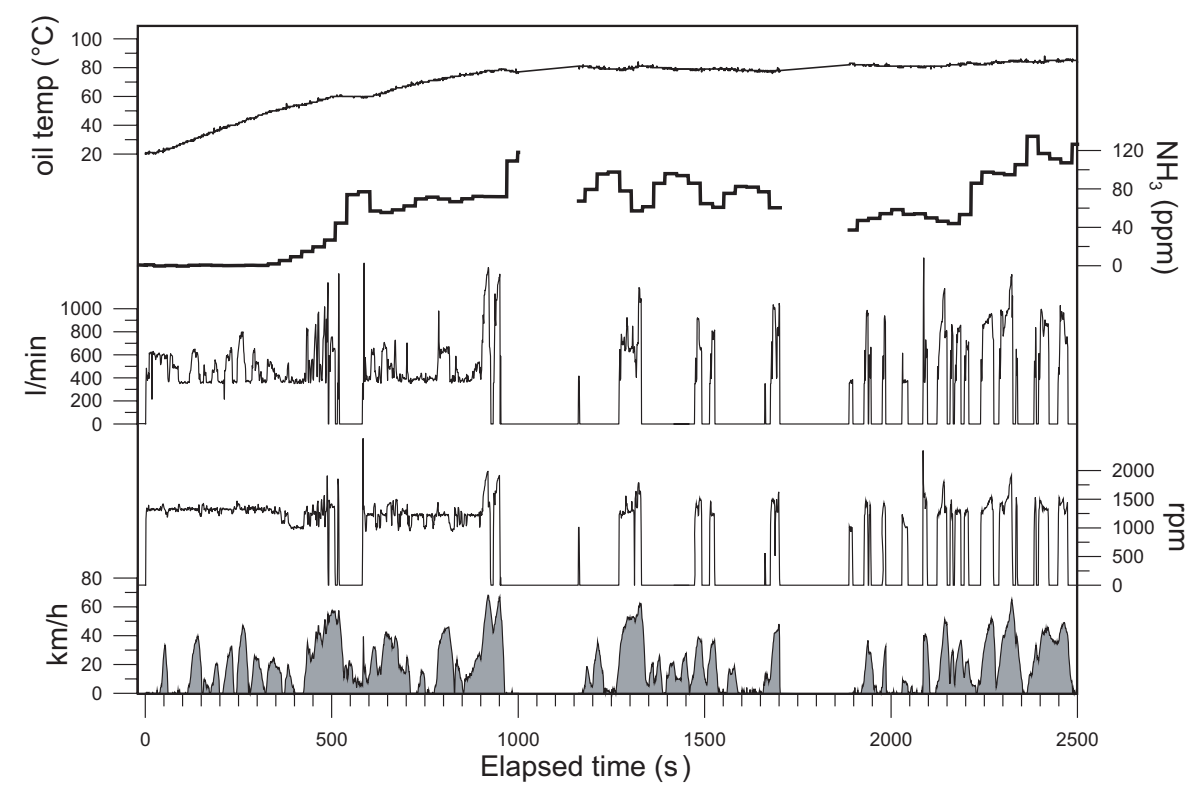

Fig. 4. Example of some of the parameters registered from the Toyota Prius during the first $2500 \mathrm{~s}$ of the MCMA-driving sequence. This section corresponds to the first three cycles (SO, CE and part of NE) run during the cold-start phase.

Table 1. Emissions from the Toyota Prius 2002 tested on a dynamometer under typical Mexico City conditions and during the hot FTP-75 cycle (Bag 3). The standard deviation from all test considered are given in brackets.

\begin{tabular}{|c|c|c|c|}
\hline Emissions & $\begin{array}{l}\text { MCMA cold-start } \\
\text { sequence }\end{array}$ & $\begin{array}{l}\text { MCMA hot-start } \\
\text { sequence }\end{array}$ & $\begin{array}{l}\text { FTP hot-start } \\
\text { phase }\end{array}$ \\
\hline $\mathrm{CO}_{2}(\mathrm{~g} / \mathrm{km})$ & $50.4(19.2)$ & $40.5(8.1)$ & $48.0(6.0)$ \\
\hline $\mathrm{CO}(\mathrm{g} / \mathrm{km})$ & $0.8(0.4)$ & $0.6(0.2)$ & $0.60(0.1)$ \\
\hline $\mathrm{NH}_{3}(\mathrm{mg} / \mathrm{km})$ & $9.4(3.2)$ & $8.8(3.0)$ & $1.56(1.0)$ \\
\hline $\mathrm{CH}_{4}(\mathrm{mg} / \mathrm{km})$ & $6.7(3.1)$ & $5.2(1.2)$ & $3.73(1.1)$ \\
\hline $\mathrm{CH}_{3} \mathrm{OH}(\mathrm{mg} / \mathrm{km})$ & $6.7(2.2)$ & $6.2(2.0)$ & $1.51(0.9)$ \\
\hline NMHC (mg/km) & $5.7(3.9)$ & $4.1(1.9)$ & $4.09(1.5)$ \\
\hline $\mathrm{N}_{2} \mathrm{O}(\mathrm{mg} / \mathrm{km})$ & $2.7(2.4)$ & $2.7(2.7)$ & $2.59(1.7)$ \\
\hline $\mathrm{NO}(\mathrm{mg} / \mathrm{km})$ & $1.6(1.4)$ & $1.7(1.1)$ & $2.83(0.9)$ \\
\hline $\mathrm{SO}_{2}(\mathrm{mg} / \mathrm{km})$ & $1.4(0.6)$ & $1.3(0.5)$ & $1.03(0.4)$ \\
\hline $\mathrm{H}_{2} \mathrm{CO}(\mathrm{mg} / \mathrm{km})$ & $0.05(0.02)$ & $0.06(0.02)$ & $0.07(0.03)$ \\
\hline
\end{tabular}

a single vehicle cannot be representative of a class of vehicles (something that is still very difficult to achieve for hybrid vehicles), it is worthwhile comparing results from multiple investigations and among different driving patterns. Not surprisingly, Table 2 indicates that emissions from hybrid vehicles are considerably lower than from fleets of conventional vehicles tested in different locations. In general, the $\mathrm{CO}_{2}$ emissions from the Prius tested here are a factor of two or more lower than from studies performed on the Toyota Prius vehicle in other locations, whereas the $\mathrm{CO}$ emissions are 2-8 times higher (see supplemental information http://www.atmos-chem-phys.net/6/5339/2006/ acp-6-5339-2006-supplement.zip). NO emissions running in the FTP hot-start cycles are also slightly higher in this evaluation when compared to the study performed by NREL, although here $\mathrm{NO}$ emissions is reported specifically rather than $\mathrm{NO}_{\mathrm{x}}\left(\mathrm{NO}+\mathrm{NO}_{2}\right)$. Fuel consumption in our study is fairly similar to the ones reported for city conditions elsewhere. EPA reports $52 \mathrm{mpg}$ (EPA, 1998) and NREL $57.3 \mathrm{mpg}$ (NREL, 2001) for cold-start conditions. The consumption results in this study were $47.8 \mathrm{mpg}$ during the coldstart and $50.6 \mathrm{mpg}$ during the hot-start of the MCMA sequence. The average fuel consumption for the hot FTP75 , however, was $73.6 \mathrm{mpg}$. Although the lack of inertial weights (higher fuel economy) in this experiment may account for most of the reduced $\mathrm{CO}_{2}$ observed, other factors such as gasoline composition and altitude are likely to make a contribution. Moreover, the considerably higher $\mathrm{CO}$ and 
Table 2. Comparison of emissions from other studies with this work.

\begin{tabular}{lllllll}
\hline Emissions & $\begin{array}{l}\mathrm{CO}_{2} \\
\mathrm{~g} / \mathrm{km}\end{array}$ & $\begin{array}{l}\mathrm{CO} \\
\mathrm{g} / \mathrm{km}\end{array}$ & $\begin{array}{l}\mathrm{NMHC} \\
\mathrm{g} / \mathrm{km}\end{array}$ & $\begin{array}{l}\mathrm{NO} \\
\mathrm{mg} / \mathrm{km}\end{array}$ & $\begin{array}{l}\mathrm{N}_{2} \mathrm{O} \\
\mathrm{mg} / \mathrm{km}\end{array}$ & $\begin{array}{l}\mathrm{NH}_{3} \\
\mathrm{mg} / \mathrm{km}\end{array}$ \\
\hline Fleet, 39-vehicle, FTP $^{\mathrm{a})}$ & - & 4.31 & 0.258 & $358^{\mathrm{g})}$ & - & 34 \\
Fleet, ages 1993-1995 $^{\mathrm{b})}$ & - & 2.11 & 0.250 & 620 & - & - \\
Prius, FTP, EPA $^{\mathrm{c})}$ & 110.0 & 0.27 & 0.035 & $32^{\mathrm{g})}$ & - & - \\
Prius, FTP, NREL $^{\mathrm{d})}$ & 98.2 & 0.07 & 0.006 & $1.9 \mathrm{~g})$ & - & - \\
Prius, FTP, Mexico $^{\mathrm{e})}$ & 49.2 & 0.62 & 0.005 & 3.22 & 1.3 & 1.5 \\
Prius, MCMA, Mexico $^{\mathrm{f})}$ & 44.0 & 0.70 & 0.005 & 1.16 & 1.3 & 9.2 \\
\hline
\end{tabular}

a) (Durbin et al., 2001) average age 1996. b) On-road measurements by Bishop (1997) in Monterrey, Mexico. c) (EPA, 1998), all 4 bags weighted. ${ }^{\text {d) }}$ (NREL, 2001), all 4 bags weighted. ${ }^{\text {) }}$ This work, FTP-75, Hot-start phase (Bag \#3 only). ${ }^{\text {f) }}$ This work, hot-start sequence. ${ }^{\text {g) }}$ $\mathrm{NO}_{\mathrm{x}}$ is reported rather than NO.

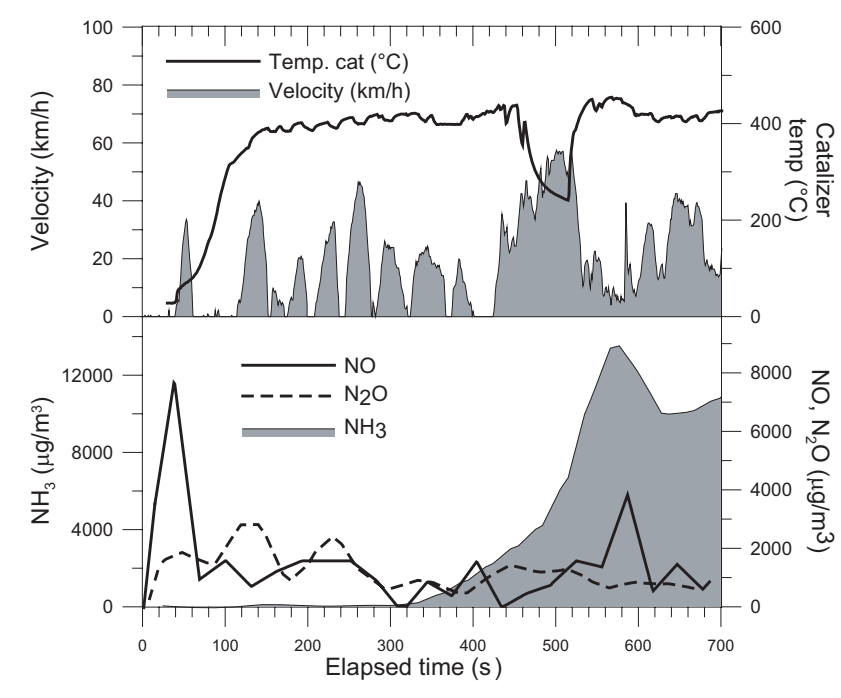

Fig. 5. Evolution of the gas concentrations at the tail-pipe of the Toyota Prius for $\mathrm{NO}, \mathrm{N}_{2} \mathrm{O}$ and $\mathrm{NH}_{3}$ (in $\mu \mathrm{g} / \mathrm{m}^{3}$ ) after cold-start of the first $700 \mathrm{~s}$ of the MCMA driving sequence.

NO emissions found in this study compared to NREL following the FTP-75 driving cycles, would suggest that these factors are affecting the emissions for which this vehicle was designed.

Although the Prius emissions of $\mathrm{NH}_{3}$ and $\mathrm{CH}_{3} \mathrm{OH}$ (shown in Table 1) are low compared to the emissions of fleets composed of conventional vehicles, it is interesting to observe such large discrepancies when different driving patterns are analyzed. Substantial sampling losses of these soluble gases are not anticipated since only less than $8 \%$ of the total exhaust water was held at the trap shown in Fig. 1. In the supplemental information (http://www.atmos-chem-phys.net/6/ 5339/2006/acp-6-5339-2006-supplement.zip) is also shown, that the amount of ammonia dissolved in the condensed water is negligible under these operating conditions. Lower driving speeds tend to release less NO per distance traveled but considerably more $\mathrm{NH}_{3}$ and $\mathrm{CH}_{3} \mathrm{OH}$ than when driving at higher speeds (FTP). This has been noted elsewhere (Heeb et al., 2004) and made evident in this study, suggesting that important uncertainties may arise when estimating the emission factors of mobile sources using different driving patterns from those practiced in that location.

Figure 5 shows the evolution of $\mathrm{NO}, \mathrm{N}_{2} \mathrm{O}$ and $\mathrm{NH}_{3}$ as the temperature of the catalytic converter increases and reaches a specific working range. In this plot one can observe that the emission of NO is rapidly reduced to very low values as the catalyst heats up after cold ignition, giving rise to moderate $\mathrm{N}_{2} \mathrm{O}$ and eventually $\mathrm{NH}_{3}$ emissions. It is also evident that since the IC engine is constantly turning on and off, happening after $400 \mathrm{~s}$ in this particular example, the temperature within the catalytic filter is not stable and may never reach a steady state in hybrid vehicles. This non-steady operation could be affecting the efficiency of the filter. The increase of $\mathrm{NO}$ and $\mathrm{NH}_{3}$ after the $\sim 2$ min cool-down observed in the plot could be a proof of this.

\section{Conclusions}

In summary, the methodology described here serves as a valuable tool to determine vehicle emissions of both regulated and unregulated gaseous pollutants. In particular, it has been shown that it can be used to measure real-time emissions from vehicles below the ULEV standards. This study presents the first reports of non-regulated emissions of a hybrid vehicle tested in a high altitude location and using the local gasoline for MCMA driving patterns. Results include the emissions of $\mathrm{CO}_{2}, \mathrm{CO}, \mathrm{CH}_{4}$, selected NMHC, $\mathrm{NO}$, $\mathrm{N}_{2} \mathrm{O}, \mathrm{NH}_{3}, \mathrm{SO}_{2}, \mathrm{H}_{2} \mathrm{CO}$ and $\mathrm{CH}_{3} \mathrm{OH}$ both for the MCMAsequence and the FTP-75 (bag \#3) driving cycles. This experimental set-up can be applied to the study of vehicles with alternative fuels, like compressed natural gas (CNG), liquefied petroleum gas (LPG), alcohol blends with Diesel and bio-Diesel. Spectroscopic techniques can be further devel- 
oped to satisfy the automotive industry needs to accurately measure the exhausts gases of newer vehicles with higher efficiencies and lower emissions. Furthermore, the detailed and on-line measurement of exhaust gas composition can be used to optimize emission control systems, as indicated above.

Future work will further optimize the FTIR analytical method for specific applications. There is a strong need to measure vehicle emissions for on-road conditions, which together with GPS data, will serve to supplement and evaluate the dynamometer studies. The data acquired for specific $\mathrm{rpm}$ and torque can be used as input for the Advisor software (NREL Advisor, 2002), which will be capable of simulating the emissions over any given route for a specific type of vehicle. This information can be extrapolated for a specific fleet composition so that the emissions inventories due to mobile sources could be improved significantly for the MCMA or other regions.

Acknowledgements. This research has been funded by UNAMDGAPA (PAPIIT-101002), SEMARNAT-CONAYT (C01-0252) and the Earth Sciences Graduate Program of UNAM.

Edited by: C. E. Kolb

\section{References}

Adachi, M.: Emission measurement techniques for advanced powertrains, Meas. Sci. Technol., 11(10), R113-R129, 2000.

ASTM: Standard test method for determination of gaseous compounds by extractive direct interface Fourier Transform Infrared (FTIR) Spectroscopy, American Society for Testing and Materials, PA, USA, 2002.

Ballantyne, V. F., Howes, P., and Stephanson, L.: Nitrous oxide emissions from light-duty vehicles, SAE Technical Paper, No. 940304, 1994.

Baronick, J., Heller, B., Lach, G., and Ramacher, B.: Impact of sulfur in gasoline on nitrous oxide and other exhaust gas components, SAE Technical Paper, No. 2000-01-0857, 2000.

Baum, M. M., Kiyomiya, E. S., Kumar, S., and Lappas, A. M., and Lord III, H. C.: Multi-component remote sensing of vehicle exhaust by dispersive absorption spectroscopy. 1. Effect of fuel type and catalyst performance, Environ. Sci. Technol., 34(13), 2851-2858, 2000.

Berges, M. G. M., Hofmann, R. M., Scharffe, D., and Crutzen, P. J.: Nitrous-oxide emissions from motor-vehicles in tunnels and their global extrapolation, J. Geophys. Res., 98, 18 527-18 531, 1993.

Bishop, G., Stedman, D., Delagarza, C. J., and Dávalos, F.: OnRoad remote sensing of vehicle Emission in Mexico, Environ. Sci. Technol., 31(12), 3505-3510, 1997.

CARB: Procedure for determination of nitrous oxide in automotive exhaust by Fourier Transform Infrared Spectroscopy, pp. 123, California Environmental Protection Agency, El Monnte, Ca, 2004.

DGN-SECOFI: Contaminación atmosférica-especificaciones sobre protección ambiental que deben reunir los combustibles fósiles líquidos y gaseosos que se usan en fuentes fijas y móviles, in NORMA Oficial Mexicana NOM-086-ECOL-1994, 1-14, México DF, 1994.

Durbin, T. D., Norbeck, J. M., Huai, T., and Rhee, S. H.: Investigation of emission rates of ammonia and other toxic and lowlevel compounds using FTIR, Final Report for the South Coast Air Quality Management District under contract No. 99131 by the Bourns College of Engineering Center for Environmental Research and Technology, September, Riverside, CA 92521, 2001.

Durbin, T. D., Wilson, R. D., Norbeck, J. M., Wayne, J. M., Huai, T., and Rhee, S. H.: Estimates of the emission rates of ammonia from light-duty vehicles using standard chassis dynamometer test cycles, Atmos. Environ., 36, 1475-1482, 2002.

EPA: Evaluation of a Toyota Prius Hybrid System (THS), United States Environmental Protection Agency (USEPA), Ann Arbor, MI 48105, 1-63, 1998.

EPA: Method 320; Measurement of vapor phase organic and inorganic emissions by extractive Fourier transform infrared (FTIR) spectroscopy, in: Federal Register, Environmental Protection Agency, 40 CFR Part 63, Appendix A to Part 63-Test Methods, (March 24, 1998), 14219-14 228, 1998a.

EPA: Fuel Economy Guide, DOE/EE-0302, U.S. Department of Energy, 1-26, 2005.

Finlayson-Pitts, B. J. and Pitts, J. N.: Chemistry of the upper and lower atmosphere, Academic Press, San Diego, California, 2000

Fraser, M. P. and Cass, G. R.: Detection of excess ammonia emissions from in-use vehicles and the implications for fine particle control, Environ. Sci. Technol., 32(8), 1053-1057, 1998.

GDF: Inventario de Emisiones de la Zona Metropolitana del Valle de México, Gobierno del Distrito Federal, Secretaria del Medio Ambiente, México D.F., 1-309, 2002.

Gertler, A. W., Sagebiel, J. C., and Cahill, T. A.: Measurements of ammonia emissions from vehicles in a highway tunnel, in Proceedings of the 11th CRC Onroad Vehicle Emissions Workshop, San Diego, CA, March, 2001

González, O. R. and Galván, Z. A.: Desarrollo de ciclos de manejo característicos de la Ciudad de México, in Memorias del IX Congreso Anual, Soc. Mex. de Ing. Mec., 535-544, 2003.

Grutter, M.: Multi-Gas analysis of ambient air using FTIR spectroscopy over Mexico City, Atmósfera, 16, 1-13, 2003a.

Grutter, M., Flores, E., Basaldud, R., and Ruiz-Suárez, L. G.: Openpath FTIR spectroscopic studies of the trace gases over Mexico City, Atmos. Ocean. Opt., 16(3), 232-236, 2003 b.

Heeb, N. V. F., Brühlmann, A. M., Lüscher, S., Saxer, R. T., and Ch. Hug, P.: Presented at 13th Int. scientific symposium on transport and air pollution, September 13-15 Boulder, CO, USA, 149-156, 2004.

IPCC: Climate Change 2001: The Scientific Basis, Contribution of Working Group I to the Third Assessment Report of the Intergovernmental Panel on Climate Change, edited by: Houghton, J. T., Ding, Y., Griggs, D. J., Noguer, M., van der Linden, P. J., Dai, X., Maskell, K., and Johnson, C. A., pp. 881, Cambridge University Press, Cambridge, United Kingdom and New York, NY, USA, 2001.

Kean, A. J., Harley, R., Littlejohn, D., and Kendall, G.: On-road measurement of ammonia and other Motor vehicle exhaust emissions, Environ. Sci. Technol., 34(17), 3535-3539, 2000.

Larry, P. H.: Comparison of Fourier Transform Infrared Spectrometry and 2,4=dinitrophenylhydrazine impinger techniques for the 
measurement of formaldehyde in vehicle exhaust, Anal. Chem., 58(1), 68-72, 1986.

Michaels, H., Fulper, C., and Kolowich, B.: Nitrous oxide emission factors for mobile sources, Presented at the AWMA Emission Inventory Conference, New Orleans, LA, 1998.

Moya, M., Grutter, M., and Baéz, A.: Diurnal variability of sizedifferentiated inorganic aerosols and their gas-phase precursors during January and February of 2003 near downtown Mexico City, Atmos. Environ., 38, 5651-5661, 2004.

Mridul, G., Gregory, J. T., Daniel, K. C., Nigel, N. C., Benjamin, C. S., Wesley, C. R., and Donald, W. L.: Measurement of InUse, on board emissions from heavy-duty diesel vehicles: Mobile emissions measurement system, SAE Technical Paper, No. 2001-01-3643, 2001.

NIOSH: Method 3800; Organic and inorganic gases by FTIR spectroscopy, in NIOSH Manual de Analytical Methods (NMAM), 1-47, 2000.

NREL: Benchmarking of OEM Hybrid Electric Vehicles at NREL, pp. 1-104, Center for Transportation Technologies and Systems. National Renewable Energy Laboratory, Golden, Colorado, USA, 2001.

NREL: ADVISOR (Advanced Vehicle Simulator), U.S. Department of Energy (DOE) and National Renewable Energy Laboratory (NREL), 2002.
Rothman, L. S., Jacquemart, D., Barbe, A., Chris Benner, D., Birk, M., Brown, L. R., Carleer, M. R., Chackerian Jr., C., Chance, K., Coudert, L. H., Dana, V., Devi, V. M., Flaud, J.-M., Gamache, R. R., Goldman, A., Hartmann, J.-M., Jucks, K. W., Maki, A. G., Mandin, J.-Y., Massie, S. T., Orphal, J., Perrin, A., Rinsland, C. P., Smith, M. A. H., Tennyson, J., Tolchenov, R. N., Toth, R. A., Vander Auwera, J., Varanasi, P., and Wagner, G.: The HITRAN 2004 molecular spectroscopy database, J. Quant. Spectrosc. Radiat. Transfer, 96, 139-204, 2005.

Santiago, C. L. and Rincón, G. P. I.: Instrumentation of the emission control laboratory at the engineering school of the National Autonomous University of Mexico, Instrumentation and Development, 4(5), 19-24, 2000.

Shores, R. C., Walker, J., Kimbrough, S., McCulloch, R. B., Rodgers, M. O., and Pearson, J. R.: Measurement of ammonia emissions from EPA's instrumented vehicle, in: Proceedings of the 10th CRC On-Road Vehicle Emissions Workshop, 2000.

VDI: Remote sensing - Atmospheric measurements near ground with FTIR spectroscopy - Measurement of gaseous emissions and immissions - Fundamentals, VDI 4211 Düsseldorf, pp. 76, Germany, 2000. 